ISSN 1982-8713

\title{
Uma "Guerra Total"? Repensando a ideologia miitar no Livro do Lorde Shang
}

\author{
A "Total War"? Rethinking Military Ideology in the Book of Lord \\ Shang.
}

\begin{abstract}
Yuri Pines; ${ }^{1}$ Tradução: André Bueno
${ }^{1}$ Professor of Asian Studies, the Hebrew University of Jerusalem, Guest Professor at Nankai University, Tianjin, China, and visiting professor at Beijing Normal University, China. E-mail: yuri.pines@mail.huji.ac.il.
\end{abstract}

Recebido em 20 de junho de 2020; Aceito em 4 de agosto de 2020.

DOI: $10.12957 /$ nearco.2020.57703

\section{Resumo}

O Livro do Senhor Shang, comumente identificado como uma das principais obras da chamada escola legalista, também representa um importante - e muito negligenciado tratado na história do pensamento militar chinês. Além de recomendações específicas sobre a guerra defensiva e ofensiva, o livro apresenta uma visão coerente do Estado que deve reestruturar suas políticas socioeconômicas e culturais para transformar cada homem em um soldado valente. O livro resume a ideologia da "guerra total", em que as diferenças entre os assuntos civis e militares são confusas. A sociedade está profundamente militarizada; o exército, por sua vez, está profundamente burocratizado. Meu artigo explora o pensamento militar do Livro de Lord Shang, enfocando suas visões de mobilização, de doutrinação dos soldados, de disciplina militar, de regras de engajamento militar e de comando militar. Além disso, lido com a questão do motivo pelo qual a ideologia militar do livro foi praticamente negligenciada após o fim da dinastia Han.

Palavras-chave: Livro do Lorde Shang. Exércitos massivos. Ideologia militar. Estados Combatentes.

\begin{abstract}
The Book of Lord Shang, which is commonly identified as a major work of the so-called Legalist school, is also an important-and much neglected-treatise in the history of Chinese military thought. Beyond specific recommendations concerning both defensive and offensive warfare, the book presents a coherent vision of the state that should restructure its socioeconomic and cultural policies so as to turn every man into a valiant
\end{abstract}


soldier. The book epitomizes the ideology of "total war," in which the differences between civilian and military affairs are blurred. The society is profoundly militarized; the army, in turn, is profoundly bureaucratized. My paper explores military thought of the Book of Lord Shang, focusing on its views of mobilization, of indoctrination of the soldiers, of military discipline, of rules of military engagement, and of military command. I furthermore deal with the question of why the book's military ideology was all but neglected after the end of the Han dynasty.

Keywords: Book of Lord Shang, mass armies, military thought, Warring States

\section{Introdução 280}

O Livro do Lorde Shang (Shangjunshu 商君書, sécs. 4ㅇ ao 3 AC) raramente é identificado como uma fonte importante para o início pensamento militar chinês. Embora suas visões de assuntos militares sejam abordadas às vezes em estudos sobre este texto antigo, ou em pesquisas sobre o início do pensamento militar chinês, elas raramente são discutidas sistematicamente, e nos estudos ocidentais são completamente ignoradas. ${ }^{281}$ À primeira vista, essa negligência parece estranha. A questão das proezas militares do estado domina o Livro do Lorde Shang. Muitos capítulos enfocam assuntos militares, seja exclusivamente (capítulos 10-12), ou esmagadoramente (19, partes de 15); e muitos outros capítulos também discutem questões militares. Na verdade, termos relacionados à guerra, como zhan 戰 ("guerra”, "guerra", "batalha”) e bing 兵 (“militar", "exército", "soldados", "armas") estão entre os

\footnotetext{
${ }^{280}$ Este artigo é o resumo atualizado a partir de uma versão mais longa em inglês (Pines 2016a). Esta pesquisa foi apoiada pela Fundação de Ciência de Israel (bolsa no 568/19) e pela Cadeira Michael William Lipson em Estudos Chineses.

${ }^{281}$ Para abordar as ideias militares do Livro do Lorde Shang nos estudos gerais deste livro, consulte, por exemplo, Tong Weimin 2013, 293-300 e Ouyang Fenglian 2009, 34-57 (ou, anteriormente, Yoshinami 1992, 255-272); para sua discussão em pesquisas gerais do pensamento militar chinês inicial, ver Fang Ke 1992, 317-333; Huang Pumin 2010: 222-226; para estudos específicos, ver Hu Bingquan 1980; Yang Hua 1999; Yang Ling 2005, 34-35. Não encontrei nenhum estudo em língua ocidental sobre o pensamento militar do Livro de Lorde Shang, exceto no meu próprio Pines 2016a.
} 
NEARCD: Revista Eletrônica de Antiguidade 2020, Volume XII, Número II - ISSN IS882-8713

Núcleo de Estudas da Antiguidade - NEA

Universidade do Estado do Rio de Janeiro

ISSN 1982-8713

mais onipresentes no texto. ${ }^{282}$ Não por acaso, os bibliógrafos da Dinastia Han (漢, 206/202 aC-220 dC) classificaram o Livro do Lorde Shang como "Literatura Principal" e "Textos Militares". ${ }^{283}$

Existem outras razões para prestar atenção ao conteúdo militar do Livro do Lorde Shang. Para lembrar, o suposto autor do livro, Shang Yang 商鞅 (também conhecido como Gongsun Yang 公孫鞅, d. $338 \mathrm{aC}$ ), liderou os exércitos Qin 秦 à uma série de vitórias magníficas, especialmente contra seu antigo empregador, o estado de Wei 魏 . Suas realizações militares foram bem reconhecidas pela posteridade imediata: na Dinastia Han, seu nome foi mencionado junto com os grandes gênios militares: Sun Wu 孫武 (Ca. 500 AC), Wu Qi 吳起 (m. 381 AC) e Sun Bin 孫臏 (Ca. 350 aC). ${ }^{284}$ Tudo isso deveria ter bastado para colocar o Livro do Lorde Shang entre os textos indispensáveis para estudiosos do pensamento militar chinês inicial. No entanto, isso não aconteceu.

A relutância dos estudiosos em se envolver com as ideias militares do Livro do Lorde Shang deriva de uma variedade de razões - da tendência geral de ignorar este texto, ao mau estado de preservação de seus capítulos "puramente militares" (10-12 e 19), e ao fato de que a exclusão de Shang Yang da lista de pensadores militares reverenciados, após a dinastia Han, pode ter causado a subsequente negligência de seu trabalho por analistas do pensamento militar chinês inicial. ${ }^{285}$ No entanto, quaisquer

\footnotetext{
${ }^{282}$ As palavras zhan e bing são mencionadas no Livro do Lorde Shang 134 e 113 vezes, respectivamente (Miao Ruosu e Wu Shiqi 1998) ; esta frequência é semelhante ao aparecimento de termos como ren 仁 (benevolência) e junzi 君子 (homem nobre) em um Lunyu 論語 ligeiramente mais curto (Analectos), em que esses termos ocorrem 109 e 107 vezes, respectivamente.

283 O capítulo bibliográfico "Yiwen zhi" 藝文志 da História da Antiga Dinastia Han (Hanshu 漢書) registra o texto de 29 capítulos Shangjun 商君 (Senhor de Shang) na seção de Mestres sob o título "Legalista" (fa jia 法家) subseção e um capítulo de 27 Gongsun Yang 公孫 鞅 (o nome original de Shang Yang) na seção Militar (bing shu 兵書) sob a prestigiosa subseção "Estrategistas" (quanmou jia 權謀家) (Hanshu 30: 1735 e 1757). Para as razões desse registro duplo, consulte Pines 2016a: 98n3.

284 Para as façanhas militares de Shang Yang, ver Shiji 5: 203-204 e o verbete Bamboo Annals (Zhushu jinian 竹書紀年) citado no Shiji 68: 2233n2. Para classificar Shang Yang entre os principais estrategistas, consulte Hanshu 23: 1085.

${ }^{285}$ Para o interesse nada brilhante dos estudiosos ocidentais no Livro de Lorde Shang, veja, Pines 2017: 45 , e outras referências. Os três capítulos "puramente militares" (10-12) do Livro de Lorde Shang são os mais curtos do livro, contando com 250-500 caracteres cada em comparação com outros capítulos que
} 
NEARCD: Revista Eletrônica de Antiguidade 2020, Volume XII, Número II - ISSN IS882-8713

Núcleo de Estudas da Antiguidade - NEA

Universidade do Estado do Rio de Janeiro

ISSN 1982-8713

que sejam as razões para essa negligência, ela é altamente lamentável. O Livro do Lorde Shang não é apenas um testemunho precioso da mentalidade dos reformadores que transformaram o estado de Qin em uma superpotência incrível, mas também contém evidências importantes para a transformação importante dos militares chineses de exércitos aristocráticos de elite em exércitos de massa baseados em camponeses. ${ }^{286} \mathrm{Em}$ particular, as ideias dos autores de como motivar os recrutas a lutar, em meio à transformação de todo o estado e da sociedade em uma formidável máquina de guerra, merecem a maior atenção.

Iniciarei minha discussão analisando o papel da guerra na ideologia geral do livro; em seguida, explorarei as visões dos autores sobre a mobilização, a doutrinação dos soldados e a disciplina militar. Na próxima seção, espero demonstrar como a ideia dos autores de "guerra total", em que as diferenças entre os assuntos civis e militares são esboçados, traz uma re-conceitualização da guerra: não apenas a sociedade é profundamente militarizada, mas o exército, por sua vez, é profundamente burocratizado. Minha penúltima seção se concentrará no capítulo 15 do Livro do Lorde Shang, no qual podemos discernir as sementes da futura cessação do alistamento universal e do retorno aos exércitos profissionais na era imperial. Concluirei minha discussão explorando as razões para a subsequente negligência do pensamento militar do Livro do Lorde Shang. Eu argumento que essa negligência não foi apenas um subproduto de rotular o livro como um texto "filosófico" ao invés de "militar", mas que também reflete uma mudança mais fundamental, longe dos exércitos baseados no recrutamento universal, que tornaram a grande importância à ideologia de guerra

contam de 800-1000 caracteres para os mais curtos até 1200 -1900 caracteres para mais. Para problemas do capítulo 19, "Dentro das fronteiras" ("Jing nei” 境内), veja a seguir no texto. Este mau estado de preservação lembra um destino semelhante de capítulos militares no Mozi 墨子 (para os quais, ver Yates 1979).

${ }^{286}$ As limitações de espaço me impedem de abordar completamente a datação de capítulos individuais do Livro do Lorde Shang (para os quais ver Pines 2017: 25-58). Basta dizer que a maioria dos capítulos discutidos no que segue vem do quarto século AEC, enquanto o capítulo 15, "Atraindo o povo" ("Lai min" 徠 民) discutido na penúltima seção, foi escrito ca. 250 AC. 
ISSN 1982-8713

no Livro de Lorde Shang irrelevante para os estrategistas imperiais e pensadores militares.

Devido às limitações de espaço, não irei abordar aqui os curtos capítulos militares (10-12) que discutem as regras do engajamento militar, a natureza do comando militar e a estratégia defensiva baseada na mobilização em massa de mulheres, idosos e os "Enfermos". A natureza desses capítulos e sua relação com Sunzi 孫子 em um caso e com os capítulos militares do Mozi 墨子 em outro foram discutidas por mim em outro lugar. ${ }^{287}$

\section{Texto de um guerreiro?}

O Livro do Lorde Shang é um texto muito peculiar: não apenas em termos de seu conteúdo, mas também em termos de sua argumentação, que classifiquei em outro lugar de "retórica alienante". ${ }^{288}$ Alguns dos capítulos do texto, incluindo os primeiros, fazem uma série de afirmações radicais que provavelmente chocaram a maior parte do público do período dos Reinos Combatentes, tanto quanto chocam muitos leitores contemporâneos. Entre essas declarações altamente controversas, as relacionadas com a guerra ocupam um lugar de destaque. A guerra é proclamada não apenas uma necessidade - uma ideia que foi compartilhada pela maioria dos primeiros pensadores chineses - mas a obrigação, a ocupação singularmente importante e desejável da política, sua razão de ser. Esta atitude de "guerreiro" distingue o Livro do Lorde Shang de qualquer texto contemporâneo importante.

A argumentação do livro a favor da guerra pode ser dividida em duas linhas principais. Primeiro, e menos controverso, é a ênfase na guerra como inevitabilidade. No capítulo 7, "Abrindo o bloqueado" ("Kai sai" 開 塞), um dos tratados filosoficamente mais sofisticados do texto, os autores explicam que a confiança no poder nos assuntos internos e externos surgiu devido à crescente complexidade da sociedade

\footnotetext{
287 Pines 2016a: 111-119.

288 Ver Pines 2012.
} 
NEARCD: Revista Eletrônica de Antiguidade 2020, Volume XII, Número II - ISSN IS882-8713

Núcleo de Estudas da Antiguidade - NEA

Universidade do Estado do Rio de Janeiro

ISSN 1982-8713

humana. ${ }^{289}$ Métodos pacíficos e morais de governo podem ter sido bons no passado, mas não são implementáveis no presente. Os autores resumem:

\begin{abstract}
$\mathrm{O}^{290}$ rei Wu tomou [o poder] pela rebelião, mas valorizou a obediência; ele lutou por Tudo-sob-o-céu, mas elevou a rendição; ele tomou [o mundo] pela força, mas o manteve pela justiça. ${ }^{291}$ Hoje em dia, os estados fortes se engajam em conquistas e anexações, enquanto os fracos se comprometem com a defesa contundente. Acima, eles não alcançam os tempos de Yu [Shun] e Xia; abaixo, eles não abraçam [os modos dos reis] Tang e Wu. ${ }^{292}$ [Os caminhos de] Tang e Wu estão bloqueados; portanto, cada estado de dez mil carros está engajado na guerra, e cada estado de mil carros está engajado na defesa. Esses caminhos foram bloqueados por muito tempo, mas os governantes contemporâneos são incapazes de descartá-los; portanto, as Três Dinastias não têm uma quarta. $(7,3)^{293}$
\end{abstract}

Os modelos do passado eram capazes de aplicar meios de governo tanto marciais quanto civis, ou mesmo focar uniformemente no último. Hoje em dia isso não é mais possível. A guerra é onipresente, e o compromisso com a guerra deve ser de importância primordial para um governante ambicioso que planeja o estabelecimento da "quarta" dinastia, ou seja, unificar "Tudo-sob-o-céu" (em outras palavras, o mundo inteiro) sob sua égide. Essa unificação foi um desiderato comum de pensadores concorrentes. ${ }^{294}$ No

\footnotetext{
${ }^{289}$ Para a filosofia da história deste capítulo, consulte Pines 2013, 31-35.

290 武王逆取而貴順，爭天下而上讓；其取之以力, 持之以義。今世強國事兼并, 弱國務 力守; 上不及虞夏之時, 而下不修湯武湯武塞, 故萬乘莫不戰, 千乘莫不守。此道之 塞久矣, 而世主莫之能開也,故三代不四.

${ }^{291}$ Lembre-se de que o Rei Wu de Zhou 周武王 (r. Ca. 1046-1042 AEC) liderou as forças rebeldes que derrubaram a dinastia Shang 商 (ca. 1600-1046 AEC); depois que a derrubada foi concluída, ele se tornou o governante legítimo de Tudo-sob-o-céu.

${ }^{292}$ Xia 夏 é uma dinastia semilendária que supostamente sucedeu ao governo do sábio tearca Shun 舜, cujo sobrenome era Yu 盧 (não confundir com o Grande Yu 禹, o lendário fundador dos Xia). Os reis Tang 湯 e Wu são os fundadores das dinastias Shang e Zhou (1046-256 aC), respectivamente. "Acima" referese à alta antiguidade, "abaixo" aos eventos do passado mais próximo.

${ }^{293}$ O número entre colchetes após cada tradução refere-se ao capítulo e à seção em minha tradução do Livro de Lorde Shang (Pines 2017), para detalhes sobre tradução e sobre alterações no original chinês (por exemplo, acréscimo de caracteres ausentes em colchetes de figura e substituição de caracteres emprestados entre parênteses). Minha tradução é baseada na utilização de três edições modernas: Jiang Lihong 1996, Gao Heng 1974 e Zhang Jue 2012.

${ }^{294}$ Ver Pines, 2000.
} 
NEARCD: Revista Eletrônica de Antiguidade 2020, Volume XII, Número II - ISSN 1982-8713

Núcleo de Estudas da Antiguidade - NEA

Universidade do Estado do Rio de Janeiro

ISSN 1982-8713

entanto, Shang Yang se distinguiu dos outros ao afirmar mais abertamente: a unificação é atingível exclusivamente por meios militares:

\begin{abstract}
Quando o nome é homenageado e os territórios são extensos a ponto de você se tornar o [Verdadeiro] Monarca: por que isso? \{É por causa da vitória na guerra.\} Quando o nome é desprezado e o território é desmembrado a ponto de perecer, por que isso? É por causa da derrota na guerra. Desde os tempos antigos até hoje, nunca aconteceu que alguém se tornasse monarca sem vitórias ou morresse sem derrotas. $(18,3)^{295}$
\end{abstract}

A guerra é o único meio de se tornar o Verdadeiro Monarca, que é o objetivo final das recomendações políticas de Shang Yang. O conceito do Verdadeiro Monarca evoluiu na metade do período dos Reinos Combatentes como um ideal do futuro unificador de Tudo-sob-o-céu. Em distinção aos atuais reis autoproclamados (wang 王) de estados regionais, e em distinção da figura sombria do rei Zhou, o Verdadeiro Monarca seria definido pela singularidade de seu governo: ele deve ser o soberano exclusivo de todo o Reino subcelestial. No discurso confucionista (mais notavelmente em textos como Mengzi 孟子 eXunzi 荀子), o Verdadeiro Monarca era comumente visto como um indivíduo soberbamente moral; é sua superioridade moral e intelectual e adesão à guerra justa que deve permitir-Ihe unificar o reino dividido e trazer paz a seus súditos. ${ }^{296}$ Em contraste, o Livro do Lorde Shang argumenta que apenas a resolução e o compromisso total com a guerra transformarão um governante no Verdadeiro Monarca.

No entanto, a guerra não é apenas a pré-condição para o triunfo do governante sobre seus rivais, é essencial para a própria sobrevivência do estado. Diz-se que a guerra forma um todo orgânico com a agricultura (sem o avanço da qual, os exércitos não terão suprimentos adequados); juntos, eles frequentemente são chamados o Um (yi 壹).

\footnotetext{
295 武王逆取而貴順，爭天下而上讓; 其取之以力, 持之以義。今世強國事兼并, 弱國務 力守; 上不及虞夏之時, 而下不修湯武湯武塞, 故萬乘莫不戰, 千乘莫不守。此道之 塞久矣, 而世主莫之能開也, 故三代不四.

${ }^{296}$ Para locus classicus dessa visão, consulte o capítulo “Discussão de assuntos militares" (“Yi bing” 議 兵 ) do Xunzi .
} 
NEARCD: Revista Eletrônica de Antiguidade 2020, Volume XII, Número II - ISSN 1982-8713

Núcleo de Estudas da Antiguidade - NEA

Universidade do Estado do Rio de Janeiro

ISSN 1982-8713

Ambas as áreas, mutuamente conectadas, são cruciais para o sucesso do estado: "os meios pelos quais o estado prospera são a agricultura e a guerra” 國之所以興者， 農戰也 (3.1). Essa afirmação, mesmo que não fosse comum no discurso político da época, provavelmente não foi polêmica por si mesma. Ainda assim, o Livro do Lorde Shang dá um passo adiante ao exaltar a guerra. No Capítulo 4, "Eliminando os fortes" (“Qu qiang” 去 強), uma das peças ideológicas centrais do livro 297 proclama:

\begin{abstract}
Quando um estado poderoso não está envolvido na guerra, o veneno se infiltra em seus intestinos; ritos, música e assuntos parasitários nascem; [o estado] certamente será desmembrado. Quando o estado trava guerra, o veneno se infiltra no inimigo; carece de rituais, música e assuntos parasitários; [o estado] certamente será forte. $(4,2)^{298}$
\end{abstract}

Esta declaração, ecoada em outro lugar (por exemplo, 13.2), representa a segunda e altamente controversa linha de argumentação pró-guerra no Livro de Lorde Shang. Em vez de destacar o papel da guerra em garantir a segurança do país, os autores enfatizam seu impacto cultural. A guerra é apresentada como o melhor remédio contra o "veneno" e os "seis parasitas", que são identificados em ambos os capítulos como relacionados à cultura tradicional (por exemplo, [Cânones de] Poemas e Documentos, ritos e música) e aos valores morais (por exemplo, benevolência e retidão, bondade e cultivo próprio, piedade filial e deveres fraternos). ${ }^{299}$ Essa evocação da guerra como meio de conter os valores tradicionais é altamente provocativa, e é duvidoso que possa tornar a guerra querida pelos segmentos conservadores da elite educada. Dado o fato de que no capítulo 4 a declaração citada acima é precedida por outra recomendação ainda mais notória para o exército realizar o que quer que o inimigo "não ouse" ou "tenha vergonha" de fazer (veja a seguir), o sentimento de alienação do leitor em relação ao texto pode aumentar ainda mais.

\footnotetext{
297 Para a posição especial deste capítulo, consulte Pines 2017, 44-45.

298 國強而不戰, 毒輸於內, 禮樂独官生, 必削; 國遂戰, 毒輸於敵國, 無禮樂蟲官, 必強。

${ }^{299}$ Existem diferentes relatos sobre os “seis parasitas" (liu shi 六䩶) no Livro do Lorde Shang; a lista mais exaustiva está em 13.4. Para uma versão alternativa, que aplica o termo "parasitas" não aos valores morais e culturais tradicionais, mas à negligência e excessos, ver 4.2 e exegese interna em 20.8 .
} 
ISSN 1982-8713

Pode-se usar facilmente as citações acima para rotular Shang Yang como um notório guerreiro, como de fato foi feito por muitos estudiosos tradicionais e modernos. No entanto, a situação é muito mais complexa. Como mostrei em outro lugar, os pronunciamentos provocativos espalhados no capítulo 4 do Livro do Lorde Shang e em alguns dos capítulos relacionados (por exemplo, capítulo 13) são moderados em outras partes do livro, e não podem ser comparados com a mensagem do texto geral. ${ }^{300}$ Tendo chocado seu público, os autores recorrem a uma argumentação muito mais moderada, principalmente por meio de seu repetido lembrete de que o objetivo final da guerra é, afinal, a paz: a paz que resultaria depois que os inimigos fossem exterminados e depois que o reino subcelestial fosse unificado. O Capítulo 18, “Traçando as políticas" (“Hua ce” 畫 策), resume:

Portanto, para erradicar guerra com guerra, até mesmo travar guerra é permitido; para erradicar o assassinato com assassinato, até mesmo o assassinato é permitido; erradicar punições com punições, mesmo tornando as punições pesadas é permitido. $(18,1)^{301}$

A guerra não é o objetivo final do estado, nem são defendidas punições severas em todo o texto. Em vez disso, estes são os meios necessários para atingir uma meta moral fundamental de reino unificado e bem ordenado, no qual a coerção não é mais necessária, "a virtude máxima é restaurada" 至德復立 (7.5), e o caminho da "benevolência e a justiça" é implementada "em tudo debaixo do céu" 述仁義於天下 (13.6). Visto desta perspectiva, a diferença entre o Livro do Lorde Shang e a maioria dos outros textos contemporâneos não é no que diz respeito ao ideal último de uma sociedade livre de violência, mas sim no que diz respeito à franqueza do primeiro quanto aos meios necessários para alcançar este bem-aventurado fim.

\footnotetext{
${ }^{300}$ Ver Pines, 2012, 96-102.

301 故以戰去戰, 雖戰可也; 以殺去殺, 雖殺可也; 以刑去刑, 雖重刑可也。
} 
NEARCD: Revista Eletrônica de Antiguidade 2020, Volume XII, Número II - ISSN 1982-8713

Núcleo de Estudas da Antiguidade - NEA

Universidade do Estado do Rio de Janeiro

ISSN 1982-8713

\section{Fazendo soldados lutarem: o problema do exército popular}

O Livro do Lorde Shang foi composto durante uma das transformações mais cruciais na história militar chinesa, quando o exército aristocrático baseado em carruagens foi substituído por exércitos de infantaria em massa baseados em recrutas camponeses, nos quais os carros (e mais tarde a cavalaria) desempenharam um papel auxiliar. ${ }^{302} \mathrm{Um}$ dos maiores problemas dos novos exércitos era treinar e disciplinar os recrutas e fazê-los lutar bravamente. Isso - além da necessidade de garantir que a maior parte da população continue engajada na agricultura - é também a principal preocupação do Livro do Lorde Shang.

Como transformar a população recalcitrante em lutadores e soldados? A solução está em compreender a natureza humana. Todos os seres humanos - elites e plebeus são motivados pela busca incessante de benefícios materiais ( $/ i$ 利) e melhoria de seu status social (ming 名, “um nome”, o termo que também se refere à reputação e fama de alguém). ${ }^{303}$ "Onde quer que o nome e o benefício se encontrem, o povo irá nessa direção" (名利之所湊, 則民道之。6.4). No entanto, isso não é uma responsabilidade para o governante. Em vez disso, esse estado de coisas pode se tornar a base de todo 0 sistema sociopolítico. Ao permitir que os súditos realizem suas aspirações legítimas por um status econômico e social, aprimorado exclusivamente por meio do sistema de classificações de mérito determinado pelo estado, o governante seria capaz de direcionar suas energias para os objetivos considerados essenciais para a prosperidade do estado, ou seja, agricultura e guerra. Os autores esclarecem:

A agricultura é o que as pessoas consideram amargo; guerra é o que as pessoas consideram perigoso. No entanto, eles enfrentam o que consideram amargo e realizam o que consideram perigoso: isso por causa do cálculo [de um nome e um benefício]. Assim, na vida [normal], as pessoas calculam os benefícios; [enfrentando] a morte, eles pensam em um (bom) nome. Não se pode deixar de investigar de onde vêm o nome e o benefício. Quando os

\footnotetext{
302 Ver Lewis 1990, 54-67; Yang Kuan 1998, 303-317.

303 Para saber a importância de ming como reputação e status nos primeiros textos políticos chineses, consulte Pines 2020.
} 
NEARCD: Revista Eletrônica de Antiguidade 2020, Volume XII, Número II - ISSN 1982-8713

Núcleo de Estudas da Antiguidade - NEA

Universidade do Estado do Rio de Janeiro

ISSN 1982-8713

benefícios vêm da terra, as pessoas utilizam plenamente sua força; quando o nome vem da guerra, o povo está pronto para morrer. $(6,5)^{304}$

Os autores expõem suas opiniões com a maior clareza. Embora nem a agricultura nem a guerra sejam naturalmente atraentes, elas podem se tornar atraentes se não houver maneiras alternativas de obter riqueza e status social elevado. Praticamente, isso significa criar um sistema que apelidei em outro lugar de "engenharia social", ou seja, projetar instituições políticas de modo a canalizar as forças sociais para fins sociais e políticos desejáveis. ${ }^{305}$ Por meio de uma combinação de incentivos positivos e negativos, o povo pode ser direcionado para qualquer ocupação considerada essencial pelo governante. O texto afirma:

Os seres humanos têm gostos e desgostos; portanto, o povo pode ser
governado. O governante deve investigar gostos e desgostos. Gostos e
desgostos são a raiz de recompensas e penalidades. A disposição do povo é
gostar de patentes e emolumentos e não gostar de punições e penalidades. O
governante estabelece os dois a fim de guiar a vontade do povo e estabelecer
o que ele deseja. $(9,3)^{306}$

Visões mais tradicionais do Livro do Lorde Shang centraram-se na defesa do texto sobre punições impiedosas como essenciais para sua mensagem. Na minha opinião, isso está incorreto. Os incentivos positivos - patentes e emolumentos - não importam menos do que punições e penalidades. Estas não são recomendações vazias. Atrás delas está a reforma mais ousada iniciada pelo histórico Shang Yang, que é a revisão completa do sistema social de Qin e a substituição da ordem aristocrática baseada na estirpe por uma nova em que o status de todos era determinado por níveis de mérito. As patentes concedidas principalmente para realizações militares ou compradas em troca de altos rendimentos de grãos - conferiam ao proprietário diversos privilégios econômicos,

\footnotetext{
304 夫農, 民之所苦; 而戰, 民之所危也。犯其所苦, 行其所危者, 計也。故民生則計利, 死則慮 名。名利之所出, 不可不審也。利出於地, 則民盡力; 名出於戰, 則民致死。

305 Pines 2016b.

306 人生而有好惡；故民可治也。人君不可以不審好惡；好惡者，賞罰之本也。夫人情好爵祿而惡 刑罰，人君設二者以御民之志，而立所欲焉。
} 
NEARCD: Revista Eletrônica de Antiguidade 2020, Volume XII, Número II - ISSN IS882-8713

Núcleo de Estudas da Antiguidade - NEA

Universidade do Estado do Rio de Janeiro

ISSN 1982-8713

sociais, legais e suntuários (ver abaixo). O material recentemente disponível e as evidências paleográficas mostram como a reforma de Shang Yang remodelou profundamente a sociedade de Qin. ${ }^{307}$ As fileiras eram particularmente importantes para motivar os soldados. O texto é inequívoco: "a forma de usar os soldados é comprometer-se com recompensas unificadoras"用兵之道，務在一賞 (6.3); “Posições e emolumentos são a essência do exército” 爵祿者, 兵之實也 (9.1). Em outro lugar, os autores explicam seu ponto por completo:

\begin{abstract}
Quando o sábio governa o estado, ele unifica recompensas, unifica punições e unifica o ensino. Quando as recompensas são unificadas, o exército não tem rivais. (17.1)... O que é chamado de "recompensas unificadoras" significa que benefícios, emolumentos, posição oficial e patente uniformemente derivam de [realizações] militares, e que não há outra maneira de dispensálos. Portanto, o instruído e o ignorante, o nobre e o vil, o corajoso e covarde, o digno e o indigno, todos utilizam plenamente sua sabedoria íntima e exaurem totalmente o poder de seus membros, saindo para morrer a serviço de seus superiores. Os bravos e os dignos de Tudo-sob-o-céu seguirão [o governante] assim como a água flui para baixo. Consequentemente, suas tropas não terão rivais e suas ordens serão implementadas em Tudo-sob-océu (17.2). ${ }^{308}$
\end{abstract}

Esta declaração simplifica inevitavelmente os assuntos militares: reduze-os ao único problema da motivação dos soldados para lutar, e este problema é ainda mais reduzido à política de recompensar soldados e oficiais meritórios com a melhoria de seu status socioeconômico, por meio do sistema de categorias de mérito. Que esse sistema criou uma forte motivação para os soldados Qin lutarem é inegável; mas não foi o único meio empregado pelo estado sob a égide de Shang Yang para facilitar façanhas militares. Não menos importante era o sistema de incentivos negativos, isto é, punição resoluta e inevitável de desertores do campo de batalha. O Livro do Lorde Shang esclarece:

\footnotetext{
307 Para uma introdução sistemática desses dados, consulte Pines 2016b; qv para referências adicionais. 308 聖人之為國也：壹賞, 壹刑, 壹教。壹賞則兵無敵。......所謂壹賞者, 利祿官爵, 摶出於兵, 無有異施也。夫固知愚, 貴賤, 勇怯, 賢不肖, 皆盡其胸臆之知, 竭其股肱之力, 出死而為上用 也。天下豪傑賢良從之如流水。是故兵無敵，而令行於天下。
} 
NEARCD: Revista Eletrônica de Antiguidade 2020, Volume XII, Número II - ISSN IS882-8713

Núcleo de Estudas da Antiguidade - NEA

Universidade do Estado do Rio de Janeiro

ISSN 1982-8713

Quando o povo é corajoso, a guerra termina com a vitória; quando o povo não é corajoso, a guerra termina em derrota. Aquele que é capaz de unificar o povo na guerra, seu povo é valente; aquele que é incapaz de unificar o povo na guerra, seu povo não é corajoso. ... Quando você entra em um estado e observa sua governança, você sabe que aquele cujo povo é utilizável é poderoso. Como posso saber se as pessoas são utilizáveis? Quando as pessoas olham para a guerra como um lobo faminto olha para a carne, as pessoas são utilizáveis. Quanto à guerra: é algo que o povo odeia. Aquele que é capaz de fazer as pessoas se deleitarem na guerra é o [Verdadeiro] Monarca. Entre as pessoas de um Estado poderoso, pais mandam seus filhos, irmãos mais velhos mandam seus irmãos mais novos, esposas mandam seus maridos, e todos dizem: "Não volte sem conquistas!" Eles também dizem: "Se você violar a lei [militar] e desobedecer às ordens, você morrerá e eu morrerei. Sob o controle do cantão ${ }^{309}$, não há lugar para fugir das fileiras do exército e os migrantes ${ }^{310}$ não podem encontrar refúgio". Para ordenar as fileiras do exército: ligue-os em esquadrões de cinco homens, diferencie-os com emblemas e prenda-os com ordens. Então, não haverá lugar para onde fugir e a derrota nunca acontecerá. Assim, as multidões dos três exércitos seguem as ordens do mesmo modo que [a água] flui [para baixo] e, mesmo enfrentando a morte, eles não recuarão. $(18,3)^{311}$

A discussão aqui se torna muito mais sofisticada. Recompensas - mesmo que boas - são insuficientes para criar um exército poderoso. Igualmente necessários são a disciplina militar estrita e o domínio do terror contra desertores e outros violadores de ordens. A inevitabilidade da punição - alcançada em parte graças ao cadastro completo da população, que torna extremamente difícil escapar do controle governamental - é a garantia do cumprimento. Então, a combinação de incentivos positivos e negativos provoca uma profunda internalização dos valores militares, ou seja, a militarização da cultura. Os soldados lutarão até a morte não por um compromisso abstrato com o

\footnotetext{
${ }^{309}$ Um cantão (xiang 鄉) é uma unidade de um subdistrito. Para sua administração, ver Bu Xianqun, 2006.

${ }^{310}$ Qianxi 遷徙 aqui se refere claramente a migrantes que nunca encontrarão refúgio em outro lugar porque foram registrados sob a jurisdição do cantão. Isso significa que escapar das fileiras do exército não é uma opção viável para um soldado ansioso para evitar a punição.

311 民勇者, 戰勝; 民不勇者, 戰敗。能壹民於戰者, 民勇; 不能壹民於戰者, 民不勇。......人其 國, 觀其治, 民用者強。奚以知民之見用者也? 民之見戰也, 如餓狼之見肉, 則民用矣。凡戰 者, 民之所惡也; 能使民樂戰者, 王。疆國之民, 父遺其子, 兄遺其弟, 妻遺其夫, 皆曰：「不 得, 無返。」又曰：「失法離令, 若死我死。鄉治之, 行間無所逃, 遷徙無所入。」行間之治, 連 $\{$ 之 $\}$ 五, 辨之以章, 束之以令, 拙 (趉) 無所處, 罷 (敗) 無所生。是以三軍之眾, 從令如 流, 死而不旋踵。
} 
NEARCD: Revista Eletrônica de Antiguidade 2020, Volume XII, Número II - ISSN 1982-8713

Núcleo de Estudas da Antiguidade - NEA

Universidade do Estado do Rio de Janeiro

ISSN 1982-8713

governante e o estado; eles podem até continuar a odiar a guerra; mas saberão que a guerra é sua única chance não apenas de sobreviver, mas também de se beneficiar.

Essa plena aceitação da guerra pela população é o principal desiderato dos autores. Embora eles chamem isso de doutrinação por um termo "confucionista" jiao 教 ("ensino" ou "instrução") ${ }^{312}$, eles não estão preocupados em criar uma ideologia militarista. Não há adoração do espírito marcial, semelhante, por exemplo, ao romano “Dulce et decorum est pro patria mori” (“É doce e glorioso morrer pela Pátria”), nem desumanização do inimigo, nem identificação da marcialidade com masculinidade. Em vez de fazer uma lavagem cerebral nas pessoas para se sacrificarem pelo estado por algum compromisso abstrato, os autores acreditam que as pessoas deveriam ser orientadas a fazer isso devido ao seu egoísmo intrínseco e imutável. Basta esclarecer os ganhos e perdas substanciais do envolvimento na guerra ou evasão dela: então o povo atenderá às demandas do estado por puro interesse próprio. 0 Capítulo 17, “Recompensas e punições" ("Shang xing" 賞 刑) explica o que significa "unificação do ensino": "as portas da riqueza e da nobreza estão exclusivamente no campo da guerra" 然富貴之門，要在戰而已矣 (17.4). Isso é o suficiente para criar o efeito mental necessário:

Portanto, pais e irmãos mais velhos, irmãos menores, conhecidos, parentes por casamento e colegas, todos dizem: "Devemos nos dedicar apenas à guerra e isso é tudo." Consequentemente, os saudáveis são devotados à guerra, os idosos e enfermos são devotados à defesa; os mortos não têm nada do que se arrepender; os vivos são cada vez mais devotados e encorajados. Isso é o que eu, seu ministro, chamo de "unificação do ensino". $O$ desejo do povo por riquezas e nobreza só cessa quando o caixão é selado. $E$ [entrar] nas portas da riqueza e da nobreza deve ser por meio do [serviço] militar. Portanto, quando ouvem falar de guerra, as pessoas se

\footnotetext{
312 Jiao é, obviamente, um termo multifacetado, cujo uso não se limita ao discurso confucionista (e em certo contexto pode se referir a puro treinamento militar). No entanto, no Livro do Lorde Shang, normalmente se refere à maneira quase confucionista de disseminar os valores adequados para a população.
} 
ISSN 1982-8713

cumprimentam; sempre que se movem ou descansam, bebem ou comem, cantam e entoam apenas sobre a guerra. $(17,4) .{ }^{313}$

As citações acima permitem compreender melhor a justaposição da guerra à cultura tradicional e aos valores morais, discutida na seção anterior. Shang Yang e seus seguidores veem a guerra como uma experiência total: o fator mais poderoso na sociedade. Quando todo camponês se torna um soldado e as distinções entre o exército e a sociedade são confusas, a guerra se torna a base da organização sociopolítica e também um importante fenômeno cultural. Qualquer coisa que impeça o compromisso total do Estado com a guerra (como as práticas tradicionais de promoção de eruditos sem méritos militares ou de disseminação de ideologias incompatíveis com políticas militares assertivas) deve ser descartada. A guerra se torna tudo: é a base de toda a ordem social.

\section{Militarização da sociedade e burocratização dos militares}

O capítulo 19, "Dentro das fronteiras" (“Jingnei” 境内) é singularmente importante para a compreensão do pensamento militar do Livro do Lorde Shang. Neste capítulo, os autores apresentam sua visão da integração completa da sociedade e do exército e o impacto dessa integração nos empreendimentos militares. A datação precisa do capítulo - que também é a primeira apresentação do sistema nascente de classificações de mérito - é discutível, mas certamente vem da época de Shang Yang ou um pouco mais tarde (ver nota 35 a seguir). A seguir, focarei duas peculiaridades principais da abordagem da guerra neste capítulo: a ideia de uma sociedade totalmente militarizada e o conceito paralelo de um exército burocratizado.

313 是父兄、昆弟、知識、婚姻、合同者, 皆曰：「務之所加, 存戰而已矣。」夫故當壯者務於 戰, 老弱者務於守; 死者不悔, 生者務勸。此臣之所謂壹教也。民之欲富貴也, 共闔棺而後止。 而富貴之門，必出於兵。是故民聞戰而相賀也；起居飲食所歌謠者，戰也。 
NEARCD: Revista Eletrônica de Antiguidade 2020, Volume XII, Número II - ISSN IS882-8713

Núcleo de Estudas da Antiguidade - NEA

Universidade do Estado do Rio de Janeiro

ISSN 1982-8713

O capítulo "Dentro das fronteiras" apresenta de forma mais coerente o sistema de recompensas e punições relacionadas ao desempenho militar; e explica totalmente como as recompensas devem influenciar a posição social de uma pessoa. Ele especifica:

As patentes militares de primeiro nível e inferiores, até as inferiores não classificadas, são chamadas de xiao, tu e cao: estão fora do sistema de patente comum. ${ }^{314}$ Aqueles da segunda classe e superiores a bugeng (quarta classe), são chamados de soldados. ${ }^{315} \mathrm{Na}$ batalha, cinco homens são organizados em um esquadrão e são registrados de acordo. Quando um membro do esquadrão foge, os outros quatro são punidos; se eles puderem atingir uma cabeça [de um inimigo], a punição é revogada. Para cada cinquenta homens há um líder de pelotão; para cada cem homens, um centurião. Em batalha, centuriões e líderes de pelotão não podem cortar cabeças [individualmente]; quando [o batalhão?] alcança 33 cabeças ou mais, eles cumprem a cota, e os líderes de pelotão e centuriões recebem um posto. $(19,3)^{316}$

A batalha torna-se algo mecânico: regulariza-se, as tarefas são claramente definidas e o rebaixamento ou promoção está intrinsecamente ligado ao seu desempenho. A menção de uma "cota" de cabeças decepadas é recorrente ao longo do capítulo, ou seja: 能攻城圍邑斬首八千已上, 則 盈 論 ; 野戰斬首斬首二千, 則 盈論 (“Ao atacar uma fortaleza sitiada, [um exército] capaz de cortar oito mil cabeças ou mais cumpriu a cota. Em uma batalha em campo aberto, [um exército] que é capaz de cortar duas mil cabeças ou mais cumpriu a cota" [19,5]).

Estas são as frases iniciais de uma longa seção que explica como cada detentor de patente é recompensado - a descrição mais antiga do sistema Qin de graus de mérito introduzido por Shang Yang. Vou pular esta seção amplamente técnica aqui e me

\footnotetext{
${ }^{314}$ A pontuação desta seção e seu significado preciso são altamente contestáveis; minha tradução depende muito de Li Ling 1991, 27. A posição exata de xiao 校, tu 徒 e cao 操 não é verificável, mas é provável que fossem soldados de infantaria (para uma visão de que eram oficiais menores, ver Tong Weimin 2012).

315 Li Ling (1991) sugere que, a julgar pelo significado original dos títulos de patente, os soldados de 2 a 4 não eram apenas soldados de infantaria, mas auxiliares de lutadores de carruagem.

316 軍爵自一級已下至小夫, 命曰校、徒、操, 出公爵。自二級已上至不更, 命曰卒。其戰也, 五 人來(束)簿為伍。一人羽而輕其四人, 能人得一首, 則復。五 $\{+\}$ 人一屯長, 百人一將。其戰, 百 將屯長不得斬首; 得三十三首以上, 盈論, 百將屯長賜爵一級。
} 
NEARCD: Revista Eletrônica de Antiguidade 2020, Volume XII, Número II - ISSN IS882-8713

Núcleo de Estudas da Antiguidade - NEA

Universidade do Estado do Rio de Janeiro

ISSN 1982-8713

concentrar em um ponto importante do segmento acima: a atribuição de cotas diferentes para cabeças decepadas ao conquistar uma fortaleza e ao lutar em um campo aberto. Essas cotas diferentes implicam que, depois que a fortaleza sitiada foi ocupada e os combatentes inimigos não tinham para onde fugir, a decapitação era a norma. Criou-se incentivos para decapitar civis não envolvidos em vez de soldados inimigos? Suspeita-se que a resposta seja positiva; mas também parece que os autores estavam cientes dessa possibilidade horrível e tentaram verificá-la:

\begin{abstract}
Após a batalha, quando cabeças [decepadas] são expostas, elas são verificadas por três dias; se o general não tiver dúvidas, ele entrega patentes de mérito a soldados e oficiais. ${ }^{317}$ Quanto à entrega de títulos de mérito: se isso não fosse feito depois de três dias de enforcamento das cabeças, os quatro subcomandantes do condado deveriam ser demitidos ${ }^{318}$, enquanto $o$ magistrado assistente e o comandante do condado deveriam ser multados. Aquele que é capaz de atingir uma cabeça de soldado com armadura, deve ser promovido a um posto; seu campo deve ser aumentado em um qing, o terreno de sua casa deve ser aumentado em nove $m u^{319}$ Para cada classificação, ele recebe o direito ${ }^{320}$ para um retentor; e então ele pode se tornar um oficial militar ou civil. $(19,6)^{321}$
\end{abstract}

A exposição de cabeças decepadas e sua verificação por três dias foi presumivelmente feita não apenas por preocupação humanitária pelas pessoas inocentes sendo massacradas, mas para evitar o aumento da concessão de fileiras:

\footnotetext{
317 Shi dafu 士大夫 aqui se refere aos detentores das quatro classes mais baixas (equivalente a shi, o segmento inferior da nobreza tradicional) e das seis classes seguintes (equivalente a dafu, ou seja, nobres de nível médio).

${ }^{318}$ Normalmente, os condados de Qin tinham um comandante (wei 尉), que é devidamente mencionado na próxima frase, portanto, claramente os quatro wei aqui são seus subordinados. Um dos capítulos militares do Mozi menciona a wei como um oficial militar cum policial de baixo escalão, semelhante ao que mais tarde ficou conhecido como Condestável (tingzhang 亭長) (Mozi chengshou, 52.47: 19 [“Homens Bei cheng” 備城門]), mas neste caso o número "quatro" é inexplicável (certamente havia mais de quatro policiais em um condado). Prefiro interpretar quatro wei como quatro subcomandantes.

319 Um qing 頃 é igual a cem mu 畧 ou 4,6 hectares (Hulsewé 1985: 19). A seção fala da alocação de campos públicos para soldados meritórios.

320 Seguindo Gao Heng (1974: 152n49), chu 除 como se referindo a nomeação.

321 以戰故, 暴首, 乃校三日, 將軍以不疑致士大夫勞爵。\{ 勞爵, 其縣過三日, 有不致士大夫 勞爵, 能 (罷) \} 其縣四尉, 訾 (貲) 由丞尉。能得甲首一者, 賞爵一級, 益田一頃, 益宅九鲗。 級除庶子一人，乃得人(入)兵官之吏。
} 
ISSN 1982-8713

afinal, a compensação pelo sucesso no campo de batalha era muito cara para ser dispensada levianamente. O texto especifica a importância singular das recompensas militares para a estrutura social e administrativa de Qin. A concessão da recompensa é realizada conjuntamente pelas autoridades militares e civis (presumivelmente, 0 general deveria se reportar às autoridades do condado, que então tinham o dever de recompensar os soldados), o que sugere a minimização das distinções entre a hierarquia militar e civil; na verdade, no estado "organizado para a guerra" ${ }^{322}$, tais distinções deveriam ter se tornado insignificantes. A falha dos administradores em recompensar os soldados merecedores é severamente punida. Esta é mais uma indicação da importância geral das recompensas militares para a vida social em Qin. Falando em termos do impacto social das patentes, o texto também é muito específico: conceder a categoria não era uma honra vã, mas dava ao proprietário diversos benefícios sociais e econômicos, como doação de campos públicos e aumento do lote da casa; eventualmente, concedia o direito de ingressar no funcionalismo. Em outro lugar $(19,7-19,8)$, o capítulo especifica outros privilégios legais e suntuários dos detentores de patente. Esse elaborado sistema de recompensas nos permite concluir que o avanço na hierarquia de fato poderia ter se tornado o principal estímulo para os soldados Qin irem para o campo de batalha.

A militarização do aparato administrativo e da sociedade como um todo foi acompanhada pela profunda burocratização do exército, como é amplamente exposto na seção final:

Quando uma fortaleza é atacada ou um povoado é cercado, o ministro das obras examina a largura e a extensão do muro; o comandante estadual divide os soldados xiao e tu por cada metro quadrado e ordena que ataquem. Ele fixa o tempo e diz: "Os primeiros a vencer serão considerados os melhores da vanguarda, os últimos serão censurados como os piores da retaguarda; aqueles que forem duas vezes censurados serão dispensados". Eles cavam túneis [sob as paredes] e empilham lenha; quando a lenha é empilhada, ela é queimada. Em cada lado da parede, dezoito

${ }^{322}$ Expressão emprestada de Lewis 2007, 30. 


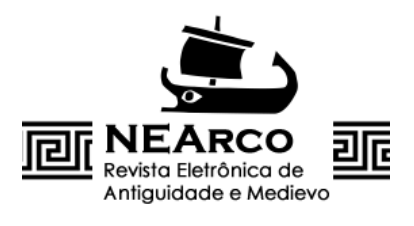

NEARCD: Revista Eletrônica de Antiguidade 2020, Volume XII, Número II - ISSN IS882-8713 Núcleo de Estudas da Antiguidade - NEA

Universidade do Estado do Rio de Janeiro

ISSN 1982-8713

sapadores devem ser colocados. Os sapadores lutam bravamente, mas não têm permissão para cortar cabeças; se cinco membros da equipe conseguem penetrar [na fortaleza], então cada sapador é recompensado com uma classificação ${ }^{323}$; se ele morrer, é transferido para um de seus herdeiros. Se [os sapadores] têm medo da morte, mil pessoas se reúnem ao redor deles; eles são advertidos ${ }^{324}$ e depois punidos sob as paredes tatuando e cortando o nariz. O comandante do estado divide as áreas [para o ataque] e as ataca com as tropas do exército central. O general cria uma plataforma de madeira e observa a operação junto com o Supervisor Chefe e o Inspetor Geral (Real?). ${ }^{325}$ Aqueles que são os primeiros a invadir [a fortaleza] são designados os melhores da vanguarda; aqueles que são os últimos a entrar, são designados os piores da retaguarda. Quanto aos sapadores, suas fileiras são totalmente preenchidas por voluntários; se não houver voluntários suficientes, eles serão complementados por aqueles que desejam promoções. $(19,9)^{326}$

Este é um relato fascinante. Em distinção de um capítulo militar anterior, "Defesa militar" ("Bing shou"兵守), escrito no estágio inicial da carreira de Shang Yang ${ }^{327}$, a guerra descrita no capítulo "Dentro das fronteiras" é puramente ofensiva. O sucesso da ofensiva depende tanto do número (os agressores têm soldados suficientes para designá-los para cada metro quadrado da parede do inimigo) quanto de transformar soldados individuais em guerreiros valentes, prontos para se sacrificar. Seu espírito de luta, previsivelmente, só pode ser mantido por meio do sistema de recompensas e

\footnotetext{
${ }^{323}$ Eu sigo aqui a identificação de Duyvendak (1963 [1928], 301) de xiandui 陷隊 como sapadores e não tropas de choque, conforme proposto por Zhu Shizhe (Gao Heng 1974, 153n62) e Zhang Jue (2012, 236n7); o pequeno número da unidade sugere que estes são de fato os sapadores.

3240 termo “admoestação" (guijian 規 諫) é normalmente usado para admoestar os superiores, mas aqui evidentemente se refere à admoestação pública dos sapadores antes que as punições sejam aplicadas.

${ }^{325}$ A questão crucial para a datação do capítulo é se ele se refere ou não a um Inspetor Geral 正御史 ou a um Inspetor Real 王御史 (a maioria das recessões usa wang 王, o que indicaria inequivocamente a composição após $325 \mathrm{AEC}$, quando o Senhor [Rei] Huiwen de Qin adotou o título real), mas a recensão altamente autorizada de Yan Wanli 嚴萬里(1762-1843) tem zheng 正, permitindo uma data anterior da composição do capítulo.

${ }^{326}$ 其攻城圍邑也, 國司空訾其城之廣厚之數; 國尉分地以徒校分積尺而攻之。為期曰：「先已者 , 當為最啟; 後已者, 訾為最殿; 再訾則廢。」内 (穴) 通則積薪, 積薪則燔柱。陷隊之士, 面 十八人。陷隊之士知疾鬥, 不得斬首; 隊五人（入）, 則陷隊之士, 人賜爵一級, 死則一人後。 不能死之, 千人環, 規諫、黥劓於城下。國尉分地, 以中卒隨之。將軍為木壹(臺), 與國正監, 與正 (王?) 御史, 參望之。其先入者, 舉為最啟; 其後入者, 舉為最殿。其陷隊也, 盡其幾（祈 ) 者; 幾者不足, 乃以欲級益之。

${ }^{327}$ Ver discussão em Pines 2016a: 116-119.
} 
ISSN 1982-8713

punições, e esse sistema de fato se torna o meio singularmente importante de manter a ofensiva. A guerra torna-se um tanto semelhante a um procedimento burocrático com oficiais (tanto do braço militar quanto do civil do governo) atribuindo meticulosamente tarefas a cada unidade e, em seguida, avaliando o desempenho. O general, sentado na plataforma de observação, parece mais preocupado com o cálculo de recompensas e punições do que com a gestão de aspectos puramente militares do ataque.

A profunda burocratização do exército pode criar a impressão de uma visão mecanicista da guerra, mas não é o caso. As tropas de choque - identificadas aqui provisoriamente como "sapadores" - são compostas por voluntários, que aparentemente estão dispostos a enfrentar a morte em troca de recompensas maiores do que as distribuídas para os soldados comuns. Se a identificação dos sapadores como voluntários estiver correta, então ela pode testemunhar o sucesso das reformas de Shang Yang: pelo menos alguns soldados Qin estavam de fato prontos para enfrentar a morte em troca de uma bela recompensa. E, como em outras partes do livro, não há incentivos espirituais para os guerreiros: matar e ser morto é apenas um procedimento de rotina para avançar na escala social.

\section{Sementes de mudança: diferenciando soldados e lavradores}

O capítulo 15, "Atraindo as pessoas" ("Lai min" 徠民) é um dos mais recentes do Livro do Lorde Shang e um dos textos mais facilmente datáveis em todo o corpus da literatura filosófica pré-Qin. A julgar pelos eventos que menciona (por exemplo, a campanha Changping 長平 de 262-260 aC), e pelo que não menciona, ou seja, a expansão imparável de Qin desde o início de $230 \mathrm{aC}$, deve ter sido produzida entre essas datas. $^{328}$

Os autores do capítulo tentam resolver um paradoxo: por que, apesar de suas sucessivas vitórias sobre os vizinhos orientais, em especial Wei 魏, Han 韓 e Zhao 趙,

${ }^{328}$ Veja Pines 2021 para mais detalhes. 
NEARCD: Revista Eletrônica de Antiguidade 2020, Volume XII, Número II - ISSN IS882-8713

Núcleo de Estudas da Antiguidade - NEA

Universidade do Estado do Rio de Janeiro

ISSN 1982-8713

Qin não consegue finalmente dominar esses estados? Essa questão tornou-se particularmente aguda após a campanha de Changping, possivelmente o maior encontro militar do período dos Reinos Combatentes. Apesar de sua vitória notável, que supostamente resultou no massacre de todo o exército Zhao de 400.000 soldados, Qin estava muito esgotado de recursos humanos e materiais para prosseguir com a conquista da capital Zhao, Handan 邯鄲. A campanha de 259-257 AEC terminou em derrota, e o objetivo da subjugação final de Tudo-sob-o-céu parecia tão evasivo como sempre. ${ }^{329}$ É neste cenário que o autor do capítulo propõe sua ideia: para vencer seus adversários, Qin deve primeiro melhorar o equilíbrio demográfico com seus rivais.

O autor do capítulo propõe uma série de políticas com o objetivo de atrair os imigrantes dos estados vizinhos rivais de Wei e Han, que sofriam de superpopulação a ponto de "mais da metade [de seu povo] ter que morar em cavernas escavadas ao longo do rio e margens da lagoa" 人之復陰陽 澤水者過半 (15.2). ${ }^{330}$ Ele recomenda que os imigrantes sejam "isentos de impostos por três gerações e não prestarão serviço militar" 復之三世, 無知軍事 além de ter permissão para a exploração gratuita de "montanhas, colinas e pântanos" por dez anos $(15,3)$. Esse tratamento tolerante aos imigrantes contrasta fortemente com a insistência dos capítulos anteriores, como o capítulo 6, em transformar todo sujeito em lavrador e soldado. ${ }^{331}$ No entanto, as vantagens desse recuo das políticas anteriores são facilmente demonstráveis:

O que preocupa Qin é que quando levantar exércitos e atacar [o inimigo], o estado ficará empobrecido, enquanto que quando ele residir em paz, com foco na agricultura, o inimigo terá uma trégua. Portanto, Vossa Majestade não pode alcançar [sucesso militar e riqueza] ao mesmo tempo. Portanto, embora [Qin] tenha sido vitorioso por quatro gerações ${ }^{332}$, Todos-sob-o-céu

\footnotetext{
329 Pines 2021. Para a campanha de Changping e suas consequências, consulte Yang Kuan 1998: 412-419.

330 Yin-yang 陰陽 refere-se aqui às margens ensolaradas e sombreadas do rio.

${ }^{331}$ Para uma comparação perceptiva, mesmo que às vezes especulativa, entre os capítulos 6 e 15 do Livro do Lorde Shang, ver Yoshinami Takashi 1985.

332 A maioria das recensões atuais tem "três" em vez de "quatro" aqui; o número exato é contestado, mas aparentemente o texto enfoca as vitórias de Qin desde o início do terceiro século AEC. Veja mais em Pines 2021.
} 
NEARCD: Revista Eletrônica de Antiguidade 2020, Volume XII, Número II - ISSN 1982-8713 Núcleo de Estudas da Antiguidade - NEA

Universidade do Estado do Rio de Janeiro

ISSN 1982-8713

não se submeteram. Agora, deixe o antigo Qin [povo] enfrentar o inimigo, e deixe o novo povo ${ }^{333}$ lidar com a [ocupação] fundamental: então, mesmo que o exército permaneça fora das fronteiras por cem dias, nenhum momento de trabalho sazonal é perdido dentro das fronteiras. Este é o resultado desejado em alcançar ambos: [ser] rico e forte. Vossa majestade, o que eu chamo de "os militares", não se refere à mobilização completa e ao recrutamento universal. O que quero dizer é que dentro das fronteiras você é capaz de fornecer o suficiente para o exército, seus soldados, carruagens e cavalaria. ${ }^{334}$ Que o antigo povo Qin sirva no exército e o novo povo forneça forragem e provisões. Quanto aos estados em Tudo-sob-o-céu que não são submissos: Vossa Majestade deve "na primavera cercar suas fazendas, no verão comer suas provisões, no outono aproveitar tudo o que colheram, no inverno expor suas reservas". ${ }^{335}$ Use o "Grande Marcial" para sacudir seus alicerces; use a "Ampla civilidade" ${ }^{336}$ para pacificar seus descendentes. ${ }^{337}$

Existem duas recomendações dignas de nota aqui. Em primeiro lugar, e a mais significativa, é a disposição dos autores de se desviar das políticas tradicionais de Qin adotadas na era de Shang Yang e de libertar parte da população (a saber, os imigrantes) do importante serviço militar. Caso esta proposta tenha sido adotada (lamentavelmente, sabemos muito pouco sobre sua implementação, além do fato indiscutível de que Qin atraiu muitos migrantes) ${ }^{338}$, significaria efetivamente dividir a população Qin em dois grupos: um segmento privilegiado envolvido no serviço militar e elegível para promoções com base no mérito militar, e outro segmento de camponeses puros, que teriam permissão para se beneficiar do solo, mas não avançariam muito socialmente. Do ponto de vista puramente militar, esse arranjo parece duplamente

\footnotetext{
333 "Velho povo Qin" são os nativos de Qin; as "novas pessoas" são imigrantes de outros lugares.

${ }^{334}$ Esta é a única referência à cavalaria em todo o Livro do Lorde Shang.

${ }^{335}$ Esta parece ser uma citação direta do capítulo “Da wu” 大武 (“O Grande Marcial”) de Yi Zhou shu 逸 周書 (Documentos Perdidos de Zhou) (Yi Zhou shu 2.8: 122); tradução segue McNeal 2012, 113.

${ }^{336} \mathrm{O}$ "Grande Marcial" é o capítulo do Yi Zhou shu citado acima; é provável que "Ampla Civilidade" se refira a outro texto, que atualmente está perdido.

${ }^{337}$ 夫秦之所患者, 興兵而伐, 則國家貧 ; 安居而農, 則敵得休息, 此王所不能兩成也。故三（四 )世戰勝，而天下不服。今以故秦事敵，而使新民作本，兵雖百宿於外，境內不失須臾之時。此富 強兩成之效也。臣之所謂兵者, 非謂悉興盡起也; 論境內所能給軍卒車騎, 令故秦民事兵, 新民 給忽食。天下有不服之國, 則王以此春圍其農, 夏食其食, 秋取其刚, 冬陳其寶。以大武搖其本 , 以廣文安其嗣。

338 Para evidências arqueológicas de imigração dos estados do leste para Qin, consulte, por exemplo, Chen Li 2009.
} 
NEARCD: Revista Eletrônica de Antiguidade 2020, Volume XII, Número II - ISSN IS882-8713

Núcleo de Estudas da Antiguidade - NEA

Universidade do Estado do Rio de Janeira

ISSN 1982-8713

vantajoso. Por um lado, o trabalho dos imigrantes poderia compensar o país pela perda de renda dos recrutas militares durante as prolongadas campanhas do final do período dos Reinos Combatentes ${ }^{339}$; por outro lado, os comandantes poderiam ser dispensados de empregar soldados estrangeiros cuja lealdade ao estado de Qin era duvidosa. Mas o que dizer da ideia acalentada de transformar toda a população em lavradores e soldados, a marca registrada das reformas de Shang Yang?

Acredito que as sementes do recuo das políticas de alistamento universal de Shang Yang, que descobrimos no capítulo "Atraindo o povo", refletem uma nova situação que emergiu na véspera da unificação imperial. À medida que os territórios de Qin se expandiam, atingindo "cinco vezes mil li ao quadrado" 方千里者五(15.1), mesmo o desempenho das funções de guarnição (shu 戌) nas fronteiras distantes poderia ter se tornado um grande fardo em termos de tempo necessário para chegar à guarnição e retorno. ${ }^{340}$ Além disso, campanhas prolongadas, como a de Changping, exigiam a mobilização ad hoc de recrutas por "cem dias" ou mais, prejudicando a produção agrícola. ${ }^{341}$ Contra esse pano de fundo, podemos entender por que o serviço militar universal não era mais considerado desejável para alguns dos estrategistas de Qin: dividir a população em dois grupos separados de soldados e lavradores poderia ser mais benéfico. No final do período dos Reinos Combatentes, as sementes foram plantadas para a futura transição do recrutamento em massa para o militar profissionalizado. ${ }^{342}$

Vamos ao segundo ponto da estratégia acima: a recomendação de travar uma guerra de atrito contra Wei e Han. Os autores citam o capítulo "O Grande Marcial" ("Da

\footnotetext{
${ }^{339}$ Veja mais em Miyake, 2015.

340 Este território de aproximadamente $800.000 \mathrm{~km}$ quadrados pode realmente refletir a extensão do governo de Qin na véspera de suas guerras finais de unificação.

${ }^{341}$ Para serviço de guarnição, consulte Barbieri-Low e Yates 2015: 891n13. Para a escassez de mão de obra durante campanhas prolongadas, consulte as medidas ad hoc adotadas pelo rei Zhaoxiang de Qin 秦昭衰 王 (r. 306-251 aC) para mobilizar todos com mais de 15 anos no estágio final da campanha de Changping (Shiji 73: 2334).

${ }^{342}$ Esse impacto da expansão territorial sobre a necessidade de substituir os recrutas por guarnições permanentes com profissionais é um padrão recorrente na história militar chinesa, como fica evidente, por exemplo, no caso Han (Lewis 2000), bem como na transformação de recrutas fubing 府兵 para exércitos profissionais na metade de Tang 唐(618-907) (ver Graff, 2002: 205-226).
} 
ISSN 1982-8713

wu” 大武) de Yi Zhou shu 逸周書: “Na primavera cercam suas fazendas, no verão comem suas provisões, no outono aproveitam tudo o que eles colheram, no inverno expõe suas provisões". Essa recomendação estereotipada pode não parecer particularmente impressionante, mas revela ainda outro aspecto da guerra total daquela época. Minar a produção agrícola do inimigo sem dúvida enfraquecia sua determinação de lutar, mas o dano à população não-combatente foi provavelmente muito mais devastador. Se a guerra do período dos Estados Combatentes de fato envolveu essa destruição deliberada de suprimentos de alimentos, podemos apreender melhor seus custos humanos. Esses custos podem, por sua vez, explicar por que a busca pela unidade e a paz resultante se tornaram o objetivo comum singularmente pronunciado dos pensadores do período dos Reinos Combatentes. ${ }^{343} \mathrm{E}$ foi Shang Yang e seus seguidores, os coautores do Livro do Lorde Shang, que forneceram as respostas mais convincentes não sobre o porquê, mas como todo o reino subcelestial deveria ser unificado.

\section{Epílogo: A Guerra Total}

O pensamento militar do Livro do Lorde Shang às vezes é reduzido a uma de suas declarações mais terríveis: "Aquele cujo exército realiza tudo o que o inimigo não se atreve a realizar, é forte; aquele que nos assuntos [militares] eleva tudo o que o inimigo tem vergonha de fazer, se beneficia”兵行敵所不敢行, 強; 事興敵所羞為, 利 (4.1). Essa recomendação pode ter dado origem a histórias de truques sujos de Shang Yang no campo de batalha, conforme narrado no Lüshi chunqiu 呂氏春秋 (Anais de primavera e outono do Sr. Lü), entre outros ${ }^{344}$; e contribuiu consideravelmente para moldar a imagem de Shang Yang e de "seu" livro como não apenas descaradamente militarista, mas também um tanto primitivo em seu compromisso com a vitória a qualquer preço. A discussão acima não atenua o militarismo de Shang Yang, mas é

\footnotetext{
${ }^{343}$ Pines, 2000.

344 Lüshi chunqiu 22.2: 1491-1492 ("Wu yi" 無 義).
} 
ISSN 1982-8713

suficiente para demonstrar a sofisticação do texto e sua colocação da guerra em uma nova estrutura conceitual. Na época em que todos estavam envolvidos na guerra - seja como recruta, ou como último defensor da fortaleza sitiada, ou como vítima de massacres, de realocação forçada da população inimiga, ou apenas de destruição sistemática da infraestrutura civil pelos exércitos do inimigo - velhos valores de cavalheirismo, de limitação do escopo dos conflitos e da indesejável violência excessiva eram obsoletos. Os autores do Livro do Lorde Shang tomaram a guerra como uma realidade dada; em vez de encontrar justificativas morais para isso, ou condenar sua crueldade, eles se concentraram em uma questão prática: como transformar todo o estado em uma máquina de guerra eficiente. A solução foi um experimento ousado em engenharia social: ao reestruturar profundamente todo o sistema social e ao transformar conquistas militares na principal forma de avanço social, Shang Yang e seus seguidores conseguiram revigorar os exércitos Qin, criando uma das máquinas militares mais formidáveis na longa história da China.

Um leitor do Livro do Lorde Shang não espera que se pondere sobre o preço da guerra. Cabeças decepadas fazem parte da cota do exército; a execução de desertores e a mutilação dos mansos são procedimentos jurídico-administrativos regulares; a mobilização de idosos e enfermos também é considerada um ato rotineiro, e a compaixão por eles é mencionada apenas como uma ameaça ao funcionamento normal do exército. A violência e a crueldade são legitimadas pelo mero fato de sua natureza cotidiana; eles são tão indispensáveis quanto os impostos e as punições legais. Assim, a ideologia de Shang Yang pode parecer mais adequada à primeira metade do século $X X$ do que a qualquer outro período da história humana. Isso distingue Shang Yang dos pensadores militares de sua época (e de períodos posteriores). Enquanto outros pensadores, principalmente os autores do Sunzi, compartilharam o entendimento do Livro do Lorde Shang de que a guerra não é decidida apenas no campo de batalha, nenhum texto que eu saiba chegou às conclusões lógicas do Livro do Lorde Shang: na era que exige compromisso total para a vitória militar, apenas a mobilização completa 
de recursos humanos e econômicos para o bem da guerra pode levar ao resultado desejável. As políticas administrativas, sociais, econômicas e educacionais - todos os aspectos imagináveis da experiência do estado - devem ser subordinadas às necessidades militares.

Em retrospecto esta atitude peculiar para a guerra - que antecipou em muitos aspectos as ideias de uma "guerra total" surgida nos sécs. 19 e 20 na Europa, mas foi muito além daqueles em termos de subordinação abrangente ao Estado da sociedade, da administração e da estrutura econômica para a necessidade de guerra - ao invés da percepção da imoralidade do texto, explica por que a ideologia militar do Livro do Lorde Shang acabou sendo lançada no esquecimento. Com o estabelecimento do império unificado, não havia mais justificativa para a mobilização abrangente de todos os recursos humanos e econômicos para o bem da guerra, uma vez que os inimigos externos, poderosos como eram, podem ter sido menos ameaçadores do que os estados rivais da época dos Estados Combatentes. O sistema de vinte categorias de mérito sofreu atrofia gradual sob a dinastia Han; mais tarde, uma variedade de razões militares, econômicas e políticas exigiram a abolição total do recrutamento universal. ${ }^{345}$ Essas mudanças tornaram o Livro do Lorde Shang um tanto irrelevante para os estrategistas militares. Paralelo a esses desenvolvimentos, e talvez não relacionado a eles, o Livro do Lorde Shang também perdeu a classificação de tratado militar e passou a ser identificado como texto de sabedoria, de modo que não foi mais consultado ou comentado por especialistas militares. Felizmente para a China, a visão de transformar o Estado em uma máquina de guerra nunca foi totalmente ressuscitada, permitindo que as ideias brilhantes - mesmo que assustadoras - de Shang Yang fossem enterradas sob a poeira da indiferença acadêmica. ${ }^{346}$

\footnotetext{
${ }^{345}$ Para a atrofia do sistema de vinte classes, consulte Korolkov 2010, 129-137 (para o antigo Han) e Brashier 2014, 163-166 (para Han tardio). Para a abolição do serviço militar universal sob o governo Han, ver Lewis 2000.

${ }^{346}$ As ideias militares de Shang Yang foram amplamente ignoradas até mesmo pelos estudiosos do período republicano (1911-1949) que estavam interessados em ideias de mobilização em massa, como Jiang Baili 將百里(1882-1938) e Lei Haizong 雷海宗(1902-1962) (para uma exceção muito rara, consulte
} 
NEARCD: Revista Eletrônica de Antiguidade 2020, Volume XII, Número II - ISSN 1982-8713

Núcleo de Estudas da Antiguidade - NEA

Universidade do Estado do Rio de Janeiro

ISSN 1982-8713

\section{Referências}

BARBIERI-LOW, Anthony J. and Robin D.S. Yates. Law, State, and Society in Early Imperial China: A study with Critical Edition and Translation of the Legal Texts from Zhangjiashan Tomb no. 247. Leiden: Brill, 2015.

BRASHIER, K.E. Public Memory in Early China. Cambridge MA: Harvard University Press, 2014.

BU Xianqun 卜憲群. “Qin Han zhi ji xiangli liyuan zakao: yi Liye Qin jian wei zhongxin de tantao” 秦漢之際鄉里吏員雜考-D以里耶秦簡為中心的探討 Nandu xuetan 南都論壇 1 , 2006: 1-6.

CHEN Li 陳力. “Cong kaogu ziliao kan Shang jun shu 'Lai min' de zhenshixing: jian tan Zhanguo wanqi Qin Xianyang fujin yimin fenbu de tedian” 從考古資料看《商君書.徠民》的真實性 : 兼論戰國晚期秦咸陽附近移民分佈的特點, Bianjiang munzu kaogu yu minzu kaoguxue jikan 邊疆民族考古與民族考古學集刊 1, 2009: 312-321.

CHEN Qitian 陳啓天. Shang Yang pingzhuan 商鞅評傳. Shanghai: Shangwu, 1935.

DUYVENDAK, Jan J.-L., tr., The Book of Lord Shang: A Classic of the Chinese School of Law. Rpt. Chicago: University of Chicago Press, 1963(1928).

FANG Ke 方克. Zhongguo junshi bianzhengfa shi (xian Qin) 中國軍事辯證法史(先秦). Beijing: Zhonghua shuju, 1992.

GAO Heng 高亨. Shangjunshu zhu yi 商君書注譯. Beijing: Zhonghua shuju, 1974.

GRAFF, David A. Medieval Chinese Warfare, 300-900. London and New York: Routledge, 2002.

BAN Gu 班固 et al. Annotated by Yan Shigu 顏師古. Han shu 漢書 Beijing: Zhonghua shuju, 1997.

HU Bingquan 胡炳權. 1980. “Lun Shang Yang de junshi sixiang一du Shangjunshu qianyi” 論商鞅 的軍事思想--讀《商君書》淺議. Hebei daxue xuebao 河北大學學報 4: 37-44.

HUANG Pumin 黄朴民. Xian Qin Liang Han bingxue wenhua yanjiu 先秦兩漢兵學文化研究. Beijing: Zhongguo Renmin Daxue chubanshe, 2010.

JIANG Lihong 蔣禮鴻. Shangjunshu zhuizhi 商君書錐指. Beijing: Zhonghua shuju, 1996.

KOROLKOV, Maxim. 'Zemel'noe zakonodatel'stvo i kontrol' gosudarstva nad zemlej v epokhu Chzhan'go i $v$ nachale ranneimperskoj epokhi (po dannym vnov' obnaruzhennykh

o estudo de Chen Qitian 陳啓天[1893-1984] sobre o Livro do Lorde Shang [1935]). Pretendo tratar dessa negligência em um estudo separado. 
NEARCD: Revista Eletrônica de Antiguidade 2020, Volume XII, Número II - ISSN 1982-8713

Núcleo de Estudas da Antiguidade - NEA

Universidade do Estado do Rio de Janeiro

ISSN 1982-8713

zakonodatel'nykh tekstov." Ph.D. thesis, Russian Academy of Sciences, Institute of Oriental Studies, 2010.

LEWIS, Mark E., Sanctioned Violence in Early China. Albany: State University of New York Press, 1990.

LEWIS, Mark E. "The Han Abolition of Universal Military Service." In Hans Van de Ven, ed., Warfare in Chinese History. Leiden: Brill, 2000: 33-76.

LEWIS, Mark E. The Early Chinese Empires: Qin and Han. Cambridge, MA: Harvard University Press, 2007.

LI Ling 李零. “Shangjunshu zhong de tudi renkou zhengce yu juezhi” 《商君書》中的土地人口 政策與爵制. Guji zhengli yu yanjiu 古籍整理與研究 6, 1991: 23-30.

Lüshi chunqiu jiaoshi 呂氏春秋校釋 Compiled and annotated by Chen Qiyou 陳奇缺. Shanghai: Xuelin, 1990.

McNEAL, Robin. Conquer and Govern: Early Chinese Military Texts from the Yi Zhou shu. Honolulu: University of Hawai'i Press, 2012.

MIYAKE Kiyoshi 宮宅潔: “Qinguo zhanyi shi yu yuanzhengjun de goucheng” 秦國戰役史與遠征 軍的構成. Jianbo 簡帛 11, 2015:153-170. (English translation in Bamboo and Silk 1.1 [2018]: 121-151).

Mozi chengshou gepian jianzhu 墨子城守各篇簡注. Compiled by Cen Zhongmian 岑仲 勉 (1886-1961). Beijing: Zhonghua shuju, 2005.

OUYANG Fenglian 歐陽鳳蓮. “Shangjunshu sixiang yanjiu”《商君書》思想研究. PhD. dissertation, Dongbei shifan daxue, 2009.

PINES, Yuri. "'The One that pervades All' in Ancient Chinese Political Thought: Origins of 'The Great Unity' Paradigm." T'oung Pao 86.4-5 (2000), 280-324.

PINES, Yuri. Envisioning Eternal Empire: Chinese Political Thought of the Warring States Era. Honolulu: University of Hawai'i Press, 2009.

PINES, Yuri. "Alienating rhetoric in the Book of Lord Shang and its moderation." Extrême-Orient, Extrême-Occident 34, 2021: 79-110.

PINES, Yuri. "From Historical Evolution to the End of History: Past, Present and Future from Shang Yang to the First Emperor." In Paul R. Goldin, ed., Dao Companion to the Philosophy of Han Fei. Berlin: Springer, 2013: 67-86.

PINES, Yuri. "A 'Total War'? Rethinking Military Ideology in the Book of Lord Shang." Journal of Chinese Military History 5.2, 2016a: 97-134. 
PINES, Yuri. "Social Engineering in Early China: The Ideology of the Shangjunshu (Book of Lord Shang) Revisited." Oriens Extremus 55 (2016b): 1-37.

PINES, Yuri. The Book of Lord Shang: Apologetics of State Power in Early China. New York: Columbia University Press, 2017.

PINES, Yuri. "To die for the Sanctity of the Name": Name (ming 名) as prime-mover of political action in early China." In Keywords in Chinese Culture, ed. Li Wai-yee and Yuri Pines. Hong Kong: The Chinese University Press, 2020.

PINES, Yuri. "Waging a Demographic War: Chapter 15 ('Attracting the People') of the Book of Lord Shang Revisited," Bochumer Jahrbuch zur Ostasienforschung 43, 2021 (forthcoming)

Shiji 史記 By Sima Qian 司馬遷 et al. Annotated by Zhang Shoujie 張守節, Sima Zhen 司馬貞, and Pei Yin 裴駰. Beijing: Zhonghua shuju, 1997.

TONG Weimin 全衛敏. “Cong Shuihudi Qin jian kan “xiao, $t u, c a o$ ” de shenfen 从睡虎地秦简看 "校、徒、操”的身份. Zhongguo guojia bowuguan guankan 中國國家博物館舘刊 2012.12: 68-72.

TONG Weimin 全衛敏. Chutu wenxian yu “Shangjunshu” zonghe yanjiu 出土文獻與《商君書 》綜合研究. Published as volumes 16 and 17 of the series Gudian wenxian yanjiu jikan 古典文 獻研究輯刊, edited by Pan Meiyue 潘美月 and Du Jiexiang 杜潔祥. Taibei: Hua Mulan chubanshe, 2013.

YANG Hua 楊華. “Shang Yang bianfa yu Qin bingzhi” 商鞅變法與秦兵制. Wenbo 文博 6, 1999: 31-34, 25.

YANG Ling 楊玲. “Guanzi he Shangjunshu bingxue sixiang bijiao"《管子》和《商君書》兵學 思想比較. Gansu gaoshi xuebao 甘肅高師學報 10.6, 2005: 32-35.

YATES, Robin D.S. "The Mohists on Warfare: Technology, Technique, and Justification." In Henry Rosemont, Jr., and Benjamin I. Schwartz, eds. Studies in Classical Chinese Thought. Journal of the American Academy of Religion 47.3, Thematic Issue, 1979: 549-603.

Yi Zhou shu huijiao jizhu 逸周書匯校集注. Compiled by Huang Huaixin 黃懷信 et al. Shanghai: Shanghai guji chubanshe, 1995.

YOSHINAMI Takashi 好并隆司. “Shōkunsho Raimin, Sanchi ryōhen yori mita Shinchō kenryōku no keisei katei 商君書徠民、算地兩篇よりみた 秦朝權力の形成過程. Tōyōshi kenkyū 44.1, 1985: 1-22.

YOSHINAMI Takashi 好并隆司. Shōkun sho kenkyū 商君書研究. Hiroshima: Keisuisha, 1992.

ZHANG Jue 張覺. Shangjunshu jiao shu 商君書校疏. Beijing: Zhishi chanquan chubanshe, 2012. 
NEARCD: Revista Eletrônica de Antiguidade 2020, Volume XII, Número II - ISSN 1982-8713 Núcleo de Estudas da Antiguidade - NEA Universidade do Estado do Rio de Janeiro

ISSN 1982-8713

Zhanguo ce zhushi 戰國策注釋. Annotated by He Jianzhang 何建章. Beijing: Zhonghua shuju, 1991.

ZHENG Liangshu 鄭良樹. Shang Yang ji qi xuepai 商鞅及其學派. Shanghai: Shanghai guji chubanshe, 1989. 